\title{
ROS1 Rearrangement Analysis
}

National Cancer Institute

\section{Source}

National Cancer Institute. ROS1 Rearrangement Analysis. NCI Thesaurus. Code C158952.

A procedure used to detect and identify rearrangements involving the ROS1 gene. 